\title{
Detection and Characterization of Infectious Bronchitis Virus in Desi Birds by Molecular Assay
}

\section{A.P. Surendar*, K.M. Palanivel, S. Saravanan and R. Gopala Krishnamurthy}

Department of veterinary preventive medicine, Veterinary College and Research Institute, Namakkal-2, Tamil Nadu Veterinary and Animal Sciences University, India

\author{
*Corresponding author
}

\section{A B S T R A C T}

\section{Keywords}

Infectious

Bronchitis,

Isolation, Detection,

RT-PCR, NP

glycoprotein.

Article Info

Accepted:

17 July 2017

Available Online:

10 September 2017
Infectious Bronchitis (IB) is highly contagious and acute, with economically importance disease of poultry. 185 samples including tracheal swab and faecal swab were collected from apparently healthy and infected birds with respiratory disorders. An attempt made to isolate the virus through inoculation of specific pathogen free embryonated egg (SPFEE) as cultural medium. The embryo showing dwarfism were identified and subjected to molecular diagnosis. Reverse transcription-polymerase chain reaction (RT-PCR) was used to amplify N-Protein and sequenced. Factors responsible for prevalence of IB in desi chicken were studied. Out of 185 samples 7 samples showed dwarfism in SPFEE. 4 out of 7 samples, found positive for IBV by RT-PCR.

\section{Introduction}

Poultry are kept in most areas of the world and it provides an acceptable form of animal protein to most people throughout the world. During the last decade, many developing countries have adopted intensive poultry production in order to meet the demand for this form of animal protein. Infectious bronchitis virus (IBV) is a major cause of disease in domestic fowl and causes an acute, highly contagious disease of the respiration and sometimes urogenital tracts (King and Cavanagh, 1991). Morbidity is usually high in all ages of chickens, drop in egg production, affect internal quality to eggs and high mortality (10\%-30\%) occurs in chickens less than 6 week old (Wang et al., 1997). Infected chicks are the major source of virus excretion in the environment. Contaminated equipment and material are a potential source for indirect transmission over large distances. Clinical signs will develop in contact chicks within 36 hours and in nearby sheds within one to two days. Infection is resolved within fourteen days with a rise in antibody titres. In a small number of chicks, latent infection is established with subsequent erratic shedding of virus for a prolonged period of time via both faeces and aerosol. Movement of live birds should be considered as a potential source for the introduction of IBV. Isolation 
and identification of IBV is needed for positive diagnosis. The preferred method of isolation is to passage a sample in SPFEE (FAO, 2010). Molecular techniques such as RT-PCR, sequencing and real time PCR, have been used for rapid and sensitive detection of IBV viral genome either in allantoic fluids from embryonated chicken eggs (ECE) inoculated with field samples or directly from the tissue samples. Several authors used different targets like the nucleoprotein gene (N-gene) (Suresh Kumar et al., 2007,), Spike protein 2 (S2) (Kumanan, 2003), Spikeprotein 1(S1) (Okino et al., 2005), M (Williams et al., 1993) to diagnose IB by RT-PCR.

However, those techniques detect only one specific pathogen at a time. The objectives of the present study were to develop RT-PCR for detection of the $\mathrm{N}$ glycoprotein genes of IBV field isolates and to sequence $\mathrm{N}$ glycoprotein genes to study genetic variation and relationships of field strain with other IBV vaccine strains. Though no disease was witnessed at the time of sampling, identified viruses including variant IBV strains, may still pose a threat for both backyard poultry and commercial poultry.

\section{Materials and Methods}

\section{Study area}

The study was conducted in organised and unorganised backyard poultry in Namakkal district, Tamil Nadu, India during October, 2016 to May, 2017.

\section{Sample collection}

A total of 27 tracheal swab and 31 rectal swab were collected from apparently healthy birds from 4 taluks of Namakkal district and were transported in $1 \%$ PBS solution to the laboratory for further processing.

\section{Reference virus (Vaccine virus- positive} control)

Vaccine virus (Massachusetts H120 strains) received from commercial market and is used for standardizing the RT-PCR protocol (Table $1)$.

\section{Virus isolation (Samples)}

The collected swabs were inoculated intra allantoically into 10 day old SPFEE.

Collection and storage of allantoic fluid from SPFEE showing dwarfism were done properly.

\section{Extraction of viral RNA}

Viral RNAs were extracted using Trizol

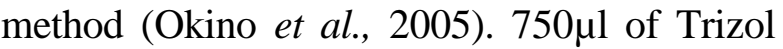
LS (Ambion) is added to $250 \mu \mathrm{l}$ of sample(gently vertex), incubate at $37^{\circ} \mathrm{C}$ for 5 min, add $200 \mu \mathrm{l}$ of chloroform, shake vigorously with hand for $15 \mathrm{sec}$, incubate at $37^{0} \mathrm{C}$ for $5 \mathrm{~min}$, centrifuge at $13000 \mathrm{rpm}$ for $15 \mathrm{~min}$ at $4^{0} \mathrm{C}$, take the aqueous phase still some good amount left, precipitate the RNA by $0.5 \mathrm{ml}$ Isopropanol (Emparta) ice cooled, incubate at $-20^{\circ} \mathrm{C}$ for $20 \mathrm{~min}$, centrifuge at $13000 \mathrm{rpm}$ for $20 \mathrm{~min}$ at $4^{0} \mathrm{C}$, remove the supernatant and add $1 \mathrm{ml}$ of $70 \%$ Ethanol (Jebsen and Jessen GmbH and Co., Germany) and vortex, centrifuge at $12000 \mathrm{rpm}$ for $5 \mathrm{~min}$ at $4^{0} \mathrm{C}$, remove the supernatant and air dry the pellet, add $20 \mu \mathrm{l}$ of nucleus free water (NFW) to the pellet, pipette it gently and thoroughly on the sides of the tube, keep the samples in the water bath at $60^{\circ} \mathrm{C}$ for $10 \mathrm{~min}$.

\section{Oligonucleotide primers}

Primers were chosen based on the cDNA sequences of genomic segments NP gene of IBV. A set of primers were used to amplify NP gene at 410bp. Primer sequences were as follows 


\section{cDNA synthesis}

RT-PCR reactions were performed according to procedures provided by Qiagen One Step RT-PCR kit (Germany). Briefly, the RT-PCR reactions were performed in $25 \mu$ l containing 5 $\mu 1$ RNA template, $5 \mu 1$ PCR Buffer mix, $1 \mu 1$ PCR enzyme mix, $1 \mu 1$ dNTP mix. $1 \mu 1 \mathrm{FP}, 1$ $\mu 1 \mathrm{RP}, 11 \mu \mathrm{l}$ NFW.A slight modifications done to RT- PCR procedure given by Liu et al., (2003). Reverse Transcription was carried out at $50^{\circ} \mathrm{C}$ for $30 \mathrm{~min}$. PCR reactions include initial denaturation for $95^{\circ} \mathrm{C}$ for $3 \mathrm{~min}$, followed by 35 cycles of denaturation for 45 seconds at $94^{\circ} \mathrm{C}$, annealing for $30 \mathrm{sec}$ at $56^{\circ} \mathrm{C}$, and extension for $30 \mathrm{sec}$ at $72^{\circ} \mathrm{C}$ and a final extension cycle at $72^{\circ} \mathrm{C}$ for $7 \mathrm{~min}$ with holding temperature of $4^{0} \mathrm{C}$.

\section{Analysis of amplified products}

After completion of PCR, $5 \mathrm{ml}$ of reaction mixture was loaded onto $1.2 \%$ agarose gels for $40 \mathrm{~min}$ at $80 \mathrm{~V}$ in $1 \%$ TAE buffer $(4.84 \mathrm{gm}$ of Tris Base, $1.142 \mathrm{ml}$ of glacial acetic acid, $2 \mathrm{ml}$ of EDTA, $\mathrm{pH}$ 8.3), containing $2 \mu 1$ ethidium bromide(Bio basic, Canada), for electrophoresis and subsequent visualization by UV transillumination. DNA ladder of $1 \mathrm{~kb}$ (Genedirex) was electrophoresed as size marker for determination of the length of the amplified fragments.

\section{Results and Discussion}

\section{Isolation of IBV}

The samples were collected from apparently healthy and clinically affected birds from four different blocks in Namakkal district. The primary symptoms observed in live birds was dyspnoea which was frequently associated with other symptoms, including apathy, diarrhoea, asthenia, locomotion ataxia, or general paralysis. Samples were processed in laboratory of Department of Veterinary Preventive Medicine, VC\&RI and Namakkal. Suspected samples were inoculated in 10 day old SPFEE. Observed every 24hrs once. Death of the embryo found in $4-5^{\text {th }}$ day. The embryo showing dwarfism in SPFEE, Allantoic fluid of that SPFEE were collected aseptically.

\section{Identification of IBV}

RNA extracted by Trizol method, cDNA synthesis done by Qiagen one step RT-PCR kit.The RNA from reference and recent isolates was reverse-transcribed to cDNA and amplified. Examination of the amplified PCR products following electrophoresis in $1.2 \%$ agarose gels indicated that all amplified cDNA showed almost identical mobilities. Amplification of the NP genes of IBV by RTPCR using primer pairs 5' -3 ' and 3' -5 ' generated a specific DNA band of $410 \mathrm{bp}$, respectively (Fig. 1), suggesting that no apparent deletions or insertions in the tested regions of NP genes of IBV. The negative controls produced no PCR products.

Seven IB-suspected field samples were subjected to RT-PCR assays. Results revealed that 410bp in length were amplified from four samples (Fig. 2). Results revealed that RTPCR provided a sensitive approach for diagnosis of IBV infections (Table 2).

Table.1 Details of PCR primers

\begin{tabular}{lcccc}
\hline Primer & Primer direction & Sequences (5'-3') & Gene location & Product size \\
\hline \multirow{2}{*}{$\begin{array}{l}\text { Forward } \\
\text { Reverse }\end{array}$} & Sense & AAT TTT GGT GATGAC AAG & & \\
& Anti-sense & ATG & N-glycoprotein & $413 \mathrm{bp}$ \\
& & CAT TGT TCC TCT CCT CAT & N-glycoprotein & $413 \mathrm{bp}$ \\
\hline
\end{tabular}


Table.2 Details of field sample positive for IBV by egg inoculation and RT-PCR

\begin{tabular}{lllllll}
\hline S.no & Place & $\begin{array}{l}\text { Type of } \\
\text { bird }\end{array}$ & $\begin{array}{l}\text { Age of } \\
\text { the bird }\end{array}$ & Samples collected & $\begin{array}{l}\text { SPFEE } \\
\text { inoculation }\end{array}$ & $\begin{array}{l}\text { RT- } \\
\text { PCR }\end{array}$ \\
\hline $\mathbf{1}$ & Thiruchengode & DB & $20 \mathrm{~W}$ & Tracheal swab & + & + \\
$\mathbf{2}$ & Ilupali & DB & $20 \mathrm{~W}$ & Tracheal swab & + & + \\
$\mathbf{3}$ & Sendhamangalam & DB & $25 \mathrm{~W}$ & Tracheal swab & + & - \\
$\mathbf{4}$ & Valaiyapatti & DB & $8 \mathrm{~W}$ & Tracheal swab & + & + \\
$\mathbf{5}$ & Kabilarmalai & DB & $18 \mathrm{~W}$ & Tracheal swab & + & - \\
$\mathbf{6}$ & Aandalurgate & DB & $10 \mathrm{~W}$ & Tracheal swab & + & + \\
$\mathbf{7}$ & Anagur & DB & $42 \mathrm{~W}$ & Tracheal swab & + & - \\
\hline
\end{tabular}

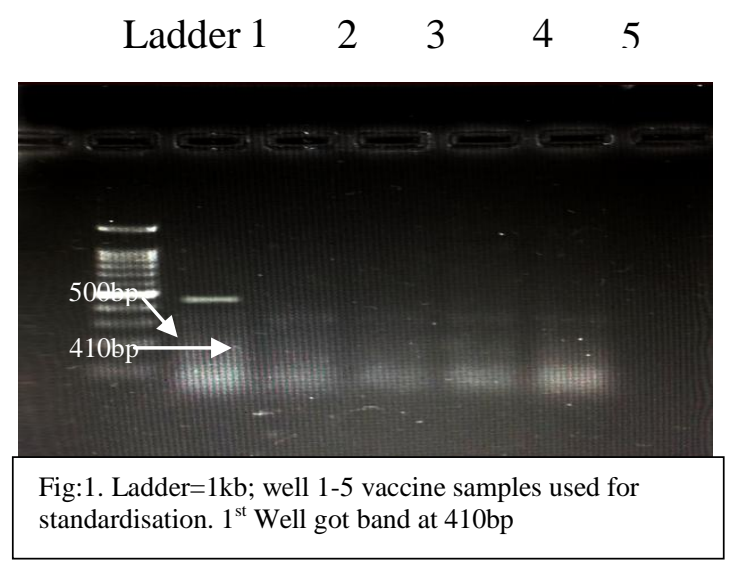

Ladder $1 \quad 2 \quad 3 \quad 4 \quad 5 \quad 6$

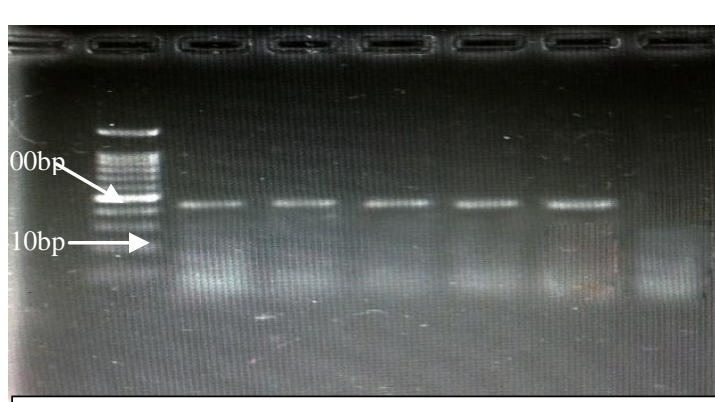

Fig:2. Ladder $=1 \mathrm{~kb} ; 1^{\text {st }}$ well-FS $1 ; 2^{\text {nd }}$ well-FS2; $3^{\text {rd }}$ wellFS $3 ; 4^{\text {th }}$ well-FS4; $5^{\text {th }}$ well- + ve control; $6^{\text {th }}$ well- -ve control.

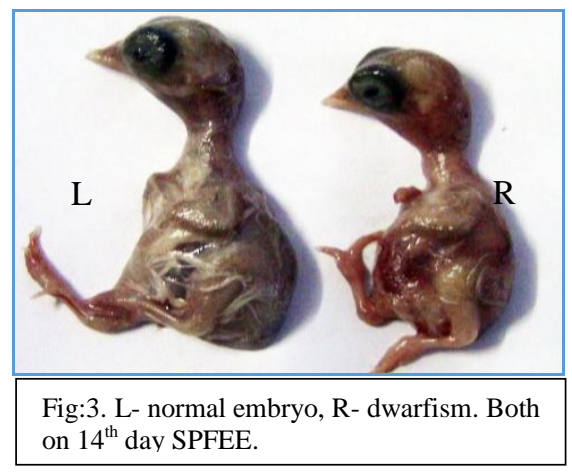

Out of 185 samples, 7 samples (3.7\%) showed dwarfism in SPFEE (Fig. 3). Out of 7 samples, 4 samples $(57.14 \%)$ showed sensitivity for RTPCR (Fig. 2). Remaining 3 samples were not shown any bands. Of the total number of samples tested for IBV from both sites $(\mathrm{n}=$ 185), 4 were positive from in and around Namakkal, resulting in an overall prevalence of $2.16 \%(4 / 185)$. All of the samples that were positive for IBV were from domestic chickens. According to the collected information, few birds were vaccinated against Newcastle disease virus (NDV), and fowl pox virus (FPV). The others were not vaccinated. There was no report of outbreak in our study areas. Desi birds near to commercial chicken farms shows presence of IBV in their flock.

This study is to identify the circulating IBV genotypes in backyard poultry of Namakkal. For this study, an epidemiologically representative number of samples were collected from four taluks of Namakkal and brought to the laboratory of the Department of 
Veterinary Preventive Medicine. Isolation done for IBV field isolates and allowed for RNA extraction once back in the laboratory, proving useful for analysing field isolates away from the point of sampling (Awad et al., 2014; Moscoso et al., 2005). Using RT-PCR we identified the prevalence of viruses within backyard flocks in relation to location and poultry species. Four samples were identified as IBV positive, with an overall prevalence of $2.16 \%$. This finding is lower than previously reported in commercial farms within Namakkal district (Chandrasekar et al., 2015). Age group of $8 \mathrm{w}-42 \mathrm{w}$ showing positive cases. However both studies sampled chickens within a higher density environment, which may have contributed to the higher prevalence rate compared with the backyard flocks. All the 4 positive samples were from non-immunized against IBV. Alert signs in the flocks were not much peculiar with morbidity, mortality, or decreased egg production. The prevalence is relatively normal in Namakkal backyard population. IBV is one of the most dangerous respiratory viruses in backyard poultry. There was no geographical significance was observed for IBV.

\section{Acknowledgments}

The work was carried out under my guidance of chairman and members, we thank to Tamil Nadu Veterinary and Animal Sciences University, Chennai, TN, India for providing facilities and fund to carry out the work. We thank to Dean, VC\&RI and Namakkal. The authors declare that they have no conflict of interest.

\section{References}

Awad, F., Baylis, M., Jones, R.C., Ganapathy, K.,
2014. Evaluation of Flinders Technology Associates cards for storage and molecular detection of avian metapneumo viruses. Avian Pathology, 43, 125-129.

Chandrasekar, A., A. Raja, G. Dhinakar Raj, A. Thangavelu, K. Kumanan, 2015. Rapid Detection of Avian Infectious Bronchitis Virus by Reverse Transcriptase-Loop Mediated Isothermal Amplification. The National Academy of Sciences, India 2015.

Food and Agricultural Organization 2010. http://www.fao.org

Hung, J., Liu, Long H. Lee, Wen L. Shih, Maw Y. Lin, Ming H. Liao (2003) Detection of infectious bronchitis virus by multiplex polymerase chain reaction and sequence analysis. Journal of Virological Methods, 109: 31-37.

Kumanan, K., Goodwin Jinesh G, Nachimuthu K 2003. A simple method of detection and typing of infectious bronchitis virus. Indian Vet J., 80:1222-1224.

Moscoso, H., Raybon, E.O., Thayer, S.G., Hofacre, C.L., 2005. Molecular detection and serotyping of infectious bronchitis virus from FTAR filter paper. Avian Diseases., 49, 24-29.

Okino, C.H., Montassier MFSM, Givisiez PEN, Furuyama CRAG, Brentano L, Montassier HJ 2005. Infectious bronchitis virus: detection and vaccine strain differentiation by semi-nested RTPCR. Braz J Poultry Sci., 7:59-66.

Suresh Kumar, K., Dhinakar Raj G, Raja A, Ramadass P 2007. Genotyping of avian infectious bronchitis viruses from India. Indian J Biotechnol., 6:45-51.

Williams, A.K., Wang L, Sneed LW, Collisson EW 1993. Analysis of a hyper variable region in the 30 non-coding end of the infectious bronchitis virus genome. Virus Res., 28:19-27.

\section{How to cite this article:}

Surendar, A.P., K.M. Palanivel, S. Saravanan and Gopala Krishnamurthy, R. 2017. Detection and Characterization of Infectious Bronchitis Virus in Desi Birds by Molecular Assay. Int.J.Curr.Microbiol.App.Sci. 6(9): 1098-1102. doi: https://doi.org/10.20546/ijcmas.2017.609.131 